\title{
Idiopathic toe walking - are common podiatric treatment options based on evidence?
}

\author{
Cylie Williams ${ }^{1,2^{*}}$, Paul Tinley ${ }^{3}$, Barry Rawicki ${ }^{4}$ \\ From Australasian Podiatry Council Conference 2013 \\ Sydney, Australia. 2-5 June 2013
}

Idiopathic toe walking (ITW) is a condition that commonly presents to podiatrists. This presentation aims to give an overview of the quality of literature focused on the treatment of ITW and determine if common podiatric treatment modalities are evidence based. 24 articles reporting treatment modalities were appraised against the National Health and Medical Research Council Levels of Evidence. There currently is no evidence of any single treatment option having long term effect on ITW gait. The highest level of evidence was in support of serial casting or surgery with some evidence supporting the use of Botulism toxin Type A.

Footwear and orthotic intervention with or without stretching programs are reported treatments with no rigorous studies to support these modalities yet anecdotally these are reported effective. This article aims update the knowledge of podiatrists, to enhance how children who present with this gait style can be managed and highlight areas for future research.

\section{Author details \\ ${ }^{1}$ Allied Health Research Unit, Southern Health, Cheltenham, VIC, 3192, Australia. ${ }^{2}$ Department of Physiotherapy, Monash University, Frankston, VIC, 3199, Australia. ${ }^{3}$ School of Podiatry, Charles Sturt University, Albury, NSW, 2460, Australia. ${ }^{4}$ Victorian Paediatric Rehabilitation Service, Monash Childrens, Clayton, VIC 3680, Australia.}

Published: 31 May 2013

doi:10.1186/1757-1146-6-S1-037

Cite this article as: Williams et al:: Idiopathic toe walking - are common podiatric treatment options based on evidence? Journal of Foot and Ankle Research 2013 6(Suppl 1):O37.

\footnotetext{
* Correspondence: cylie.williams@southernhealth.org.au

${ }^{1}$ Allied Health Research Unit, Southern Health, Cheltenham, VIC, 3192, Australia

Full list of author information is available at the end of the article
}

Submit your next manuscript to BioMed Central and take full advantage of:

- Convenient online submission

- Thorough peer review

- No space constraints or color figure charges

- Immediate publication on acceptance

- Inclusion in PubMed, CAS, Scopus and Google Scholar

- Research which is freely available for redistribution

Submit your manuscript at www.biomedcentral.com/submit

\section{() Biomed Central}

C Biomed Central

C 2013 Williams et al; licensee BioMed Central Ltd. This is an Open Access article distributed under the terms of the Creative Commons Attribution License (http://creativecommons.org/licenses/by/2.0), which permits unrestricted use, distribution, and reproduction in any medium, provided the original work is properly cited. 